\title{
FISH INFORMATION DATABASES CONSTRUCTION: DATA PREPARATION AND OBJECT-ORIENTED SYSTEM ANALYSIS
}

O. Klyuchko, kelenaXX@ukr.net, Kavetsky Institute of Experimental Pathology, Oncology and Radiobiology NAS of Ukraine, Kyiv

L. Buchatsky, irido1@bigmir.net, Institute of Fisheries NAAS of Ukraine, Kyiv

O. Melezhyk, o melezhyk@ukr.net, Open International University of Human Development "Ukraine", Kyiv

Purpose. The purpose of the work was to demonstrate the applications of methods of database construction on the example of information about rainbow trout and viral infections affecting it. In process of such databases construction for electronic information systems it is necessary to find the ways of biological data preparation for each of solved tasks, than to make an adequate processing of these input data. Further step is the use of the methods of object-oriented system analysis for the aforementioned database construction in optimal way.

Methodology. The methods of object-oriented system analysis, ER-diagram design, and the methods of computer databases construction were used in process of present work fulfillment.

Findings. At the initial stage of the work some fish databases known in the world were observed. The peculiarities of biological objects (fishes) that have to be taken into account for this task fulfillment were analyzed. Further the approach of object-oriented analysis for constructing of computer databases in optimal manner was suggested. The first logical steps of algorithm for construction of databases with relative information about fish were described as well the practical recommendations for the development of databases with information concerning domestic biological organisms (on example of rainbow trout, its viral infection) for electronic information systems were done.

Originality. No large-scale implementation of contemporary information-computer technologies in Ukraine was done yet. The obtained results would be contributed to further intensive implementation of contemporary information technologies for the development of domestic fishery industry.

Practical value. Rainbow trout is important specie for fishery economy; its studying as well as viral infections affecting it are of great value for food safety. Information computer technologies application suggested in the work would make this branch of economy more effective in Ukraine and in the whole world.

Keywords: fish, fishery economy, trout, databases, electronic information systems objectoriented system analysis.

\section{КОНСТРУЮВАННЯ ІНФОРМАЦІЙНИХ БАЗ ДАНИХ РИБ: ПІДГОТОВКА ДАНИХ І ОБ'ЄКТНО-ОРІЄНТОВАНИЙ СИСТЕМНИЙ АНАЛІЗ}

О. М. Ключко, kelenaXX@ukr.net, Інститут експериментальної патології, онкології і радіобіології ім. М.В. Кавецького НАН України, м. Київ

л. П. Бучацький, irido1@bigmir.net, Інститут рибного господарства НААН України, М. Київ

О. В. Мележик, o melezhyk@ukr.net, Відкритий міжнародний університет розвитку людини «Україна», м. Київ

(C) O. Klyuchko, L. Buchatsky, O. Melezhyk, 2019 
Мета. Мета роботи - продемонструвати застосування методів створення бази даних риб на прикладі інформації про райдужну форель та вірусні інфекції, що ії уражують. У процесі конструювання таких баз даних для електронних інформаційних систем необхідно визначити шляхи підготовки біологічних показників для кожного з вирішуваних завдань, надалі здійснити адекватну обробку цих вхідних даних. Наступним кроком є застосування методів об'єктно-орієнтованого системного аналізу для побудови біологічної бази даних оптимальним чином.

Методика. У процесі виконання робіт використано методи об'єктно-орієнтованого системного аналізу, проектування ER-діаграм, методи конструювання комп'ютерних баз даних.

Результати. На початковому етапі було виконано огляд низки відомих у світі баз даних риб. Проаналізовано особливості біологічних об'єктів (риб), які необхідно враховувати при конструюванні баз даних. Надалі запропоновано підхід об'єктно-орієнтованого аналізу для конструювання комп'ютерних баз даних оптимальним чином. Описано перші логічні етапи алгоритму конструювання баз даних з відповідною інформацією, а також практичні рекомендації з розробки баз даних з інформачією про вітчизняні біологічні організми (на прикладі райдужної форелі, їі вірусних інфекцій) для електронних інформаційних систем.

Наукова новизна. Маситабне впровадження сучасних інформаційно-комп'ютерних технологій на основі біологічних баз даних в Україні ще не здійснено. Отримані результати сприятимуть подальшому інтенсивному впровадженню сучасних інформаційних технологій для розвитку вітчизняної рибної промисловості.

Практична значимість. Райдужна форель є чінним об'єктом для рибного господарства; дослідження ії особливостей та вірусних інфекцій, що ії уражують, мають суттєве значення для продовольчої безпеки. Застосування інформаційних комп'ютерних технологій, запропонованих у роботі, зробить цю галузь економіки в Україні та світі більш ефективною.

Ключові слова: риба, рибне господарство, форель, бази даних, електронно-інформачійні системи, об'єктно-орієнтований системний аналіз.

\title{
КОНСТРУИРОВАНИЕ ИНФОРМАЦИОННЫХ БАЗ ДАННЫХ РЫБ: ПОДГОТОВКА ДАННЫХ И ОБЪЕКТНО-ОРИЕНТИРОВАННЫЙ СИСТЕМНЫЙ АНАЛИЗ
}

\author{
Е. М. Ключко, kelenaXX@ukr.net, Институт экспериментальной патологии, \\ онкологии и радиобиологии им. М.В. Кавецкого НАН Украины, г. Киев
}

л. П. Бучацкий, irido1@bigmir.net, Институт рыбного хозяйства НААН Украины, г. Киев

О. В. Мележик, o melezhyk@ukr.net, Открытый международный университет развития человека «Украина», г. Киев

Цель. Цель работы - продемонстрировать применение методов создания базы данных рыб на примере информации о радужной форели и поражающих ее вирусных инфекциях. В процессе конструирования таких баз данных для электронных информационных систем необходимо определить пути подготовки биологических показателей для каждого решаемого задания, в дальнейшем осуществить адекватную обработку этих входных данных. Следующий шаг - это применение объектно-ориентированного системного анализа для построения биологической базы данных оптимальным образом.

Методика. В процессе выполнения работы использованы методы объектноориентированного системного анализа, проектирование ER-диаграмм, методы конструирования компьютерных баз данных.

Результаты. На начальном этапе был выполнен обзор ряда известных в мире баз данных рыб. Проанализированы особенности биологических объектов (рыб), которые необходимо учитывать при конструировании баз данных. Далее предложен подход объектно- 
ориентированного анализа для конструирования компьютерных баз данных оптимальным образом. Описаны первые логические этапы алгоритма конструирования баз данных с соответствующей информацией, а также практические рекомендации по разработке баз данных с информацией об отечественных биологчческих объектах (на примере радужной форели, ее вирусных инфекций) для электронных информационных систем.

Научная новизна. Маситабное внедрение современных информационно-компьютерных технологий на основании баз данных в Украине еще не осуществлено. Полученные результаты будут способствовать дальнейшему интенсивному внедрению современных информационных технологий для развития отечественной рыбной промышленности.

Практическое значение. Радужная форель является ченным объектом для рыбного хозяйства; исследование ее особенностей и поражающих ее вирусных инфекций имеет существенное значение для продовольственной безопасности. Использование информационных компьютерных технологий, предложенных в работе, сделает эту сферу экономики в Украине и мире более эффрективной.

Ключевые слова: рыба, рыбное хозяйство, форель, базы данных, электронноинформационные системы, объектно-ориентированный системный анализ.

\section{PROBLEM STATEMENT AND ANALYSIS OF THE LAST STUDIES AND PUBLICATIONS}

Biodiversity of species is a beautiful treasure that the Nature gave us. However during the last two decades, the development of information and computer technology (ICT) gives us a possibility not to understand only the beauty and grandeur of biodiversity, but also to display them in adequate numerical characteristics, to organize vast amounts of information about living organisms in databases that allow this information automatic processing. Respectively, the possibility of the new methods of science-intensive economy organization, its control, the account of biological organisms for the purpose of their protection, and etc. appeared with ICT development. In addition to the reports, tables, lists of species in the past, that biologists of previous generations prepared carefully that play an important role in conservation measures, pest control, increase of productivity and prevent starvation of the population, modern ICTs offer new methods and tools. One of the important sets of such ICT methods is the development of databases (DB) of living organisms with further their connection to electronic information systems (ICs).

In our previous publications, we have already written about the development of such ICs with DB in Ukraine for fishes [1] and arthropods [2, 3, 24]. We set ourselves the goal to contribute to the development of living organisms databases in Ukraine (and, first of all, fish DB), linked with ISs that visualized DB in the Internet. The development of IS with DB of living organisms (including fishes) is becoming more popular and more widespread in the world today [4-23]. However, the electronic databases of organisms developed by the inhabitants of each country who knows local fauna and the most interested in such ISs have the greatest value [24]. Therefore, in our own work we based, first of all, on fish research of contemporary scientists of Ukraine [25-41, 52, 58]. In previous publications our experience of DBs construction for biology is disclosed [42-51] as well as the achievements of other professionals in DBs construction was also studied during this work [55-57]. In one of our previous articles the authors have already published the results of some theoretical generalizations of the first stages of fishes' DB development [1]. Present work is its continuation with the practical recommendations for application of previously described methods of the DB development. 
An overview of some foreign fish databases. Fishery industry is an important component of economies in many countries of the world. That is why successful experience on the development of fish databases exists already (industrial DBs and high-quality amateur DBs) [4-23]. A brief review of some fish databases we have already given [1]. In present work we would like to continue the works in this direction on example of rainbow trout, and to add more material about word fish databases.

"FishTraits Database" is known in the world database [22]. It was written that "the need for integrated and widely accessible sources of species traits data to facilitate studies of ecology, conservation, and management has motivated development of traits databases for various taxa. In spite of the increasing number of traits-based analyses of freshwater fishes in the United States, no consolidated database of traits of this group exists publicly, and much useful information on these species is documented only in obscure sources. The largely inaccessible and unconsolidated traits information makes large-scale analysis involving many fishes and/or traits particularly challenging". Characterizing this DB the authors gave the following information: ".FishTraits is a database of more than 100 traits for 809 (731 native and 78 exotic) fish species found in freshwaters of the conterminous United States, including 37 native families and 145 native genera. The database contains information concerning four major categories of traits: (1) trophic ecology, (2) body size and reproductive ecology (life history), (3) habitat associations, and (4) salinity and temperature tolerances. Information on geographic distribution and conservation status is also included. Together, we refer to the traits, distribution, and conservation status information as attributes. Descriptions of attributes are available here. Many sources were consulted to compile attributes, including state and regional species accounts and other databases.

FishTraits provides many opportunities for conducting research on fish species traits and constitutes the first step toward establishing a central repository for a continually expanding set of traits and species of North" [22].

"SalmonDB" is another important new multiorganism database [23] containing the information about fishes' genome sequences, for example, EST sequences from Salmo salar, Oncorhynchus mykiss and the whole genome sequence of Danio rerio, Gasterosteus aculeatus, Tetraodon nigroviridis, Oryzias latipes and Takifugu rubripes, built with core components from GMOD project, GOPArc system and the BioMart project. The information provided by this resource includes Gene Ontology terms, metabolic pathways, SNP prediction, CDS prediction, orthologs prediction, several precalculated BLAST searches and domains. SalmonDB also provides a BLAST server for matching user-provided sequences to any of the databases and an advanced query tool (BioMart) that allows easy browsing of EST databases with userdefined criteria. These tools make SalmonDB database a valuable resource for researchers searching for transcripts and genomic information regarding $S$. salar and other salmonid species. The database is expected to grow in the near feature, particularly with the $S$. salar genome sequencing project [23].

\section{DEFINING OF PARTS OF THE PROBLEM THAT WERE NOT SOLVED BEFORE. THE PURPOSE OF THE WORK}

In process of fish computer databases construction for electronic information systems it is necessary to find the ways of biological data preparation for each of solved tasks, than to make an adequate processing of these input data. Further it is necessary to 
use the methods of object-oriented system analysis for the successful construction of biological database in optimal way and among them - the method of design of ERdiagram as result of analysis of the future DB content organization. Below the authors will demonstrate all of these methods applications on the example of database with the data about rainbow trout, its' viral infections, and virus carrier.

\section{MATERIALS AND METHODS}

The methods of analysis of objects, potentially suitable for ordering in database, object-oriented system analysis, ER-diagram design, and the methods of computer databases construction were used in process of the work fulfillment.

\section{RESULTS OF THE STUDIES AND THEIR DISCUSSION}

Features of biological objects that are important for databases construction. Lets consider some important features of biological objects that are necessary to take into account for databases construction [53]. From the very beginning of the practice of biological data processing it was noted that during the application of information technologies/computer technologies (IT/CT) in the field of biology it was necessary to remember the following features of the objects of nature, which complicate the computer processing of data and results. First of all, it was necessary to concentrate our attention on the problem of complexity of biological objects, which had several reasons.

1. The first of the reasons - objective - is the complexity of biological organisms by itself. After all, there are millions of species on the Earth that are characterized by great variability of individual organisms, populations, and so on. The species have complex chemistry, physiology, developmental cycles and behavior, which are the result of millions of years of evolution. There are hundreds, if not thousands of ecosystems, in which many species are inked between themselves with a large number of complex relationships.

2. The second reason of the complexity is a subjective one. Since ecosystems are located in different territories of different countries, they often interfere with the interests of different groups of people: scientific, economic, commercial, others; and this is reflected on the process their data registration for future DB. Observational data obtained in different ecosystems often differ in precision and accuracy; they are made in different meteorological or geographical conditions. Many of these observations (often valuable) were made by amateurs. It is clear that all such field data observations and experiments when creating electronic databases should be formalized, unified and standardized.

If to speak about genetic material that characterizes certain types of ecosystems, then obtained data are really accurate, meet generally accepted standards and they are often the ideal material for development of electronic databases and ISs. The ambiguity arises when IT professional during his work must match these exact data, for example, with the name of the type. But the fullness of the names of the kinds of humanity still does not exist; the systematic of species is constantly revised, the evolutionary changes of organisms happen constantly, and many species on the Earth still have no names... This situation complicates greatly the use of IT/CT in biology.

The application of IT/CT in biology is complicated also the fact that most of the 
existing computer methods were developed for certain conditions, certain tasks, limited time periods. In reality, scientists deal with evolution, processes that are developing during hundreds and thousands of years, organisms that consist of billions of molecules. To solve such problems the standard methods do not exist yet, they need to be invented and developed. With simple transfer of the already developed techniques or precise discipline methods a large amount of valuable biologic information is lost.

A particular problem is the digitization of biological data accumulated over the centuries; all modern biological knowledge is based on such digitalization. So, even in the United States on 2001, where the biological data digitalization was initiated, it was necessary to digitize information on more than 750 million biological species [53]. So, this task needs to be solved globally, despite the fact that it is extremely labourintensive.

This is only a brief list of biological objects specific characteristics that are need to be taken into account during the biological databases development. Addtional list of such specific for biological objects characteristics is given in our articles [2, 3, 24].

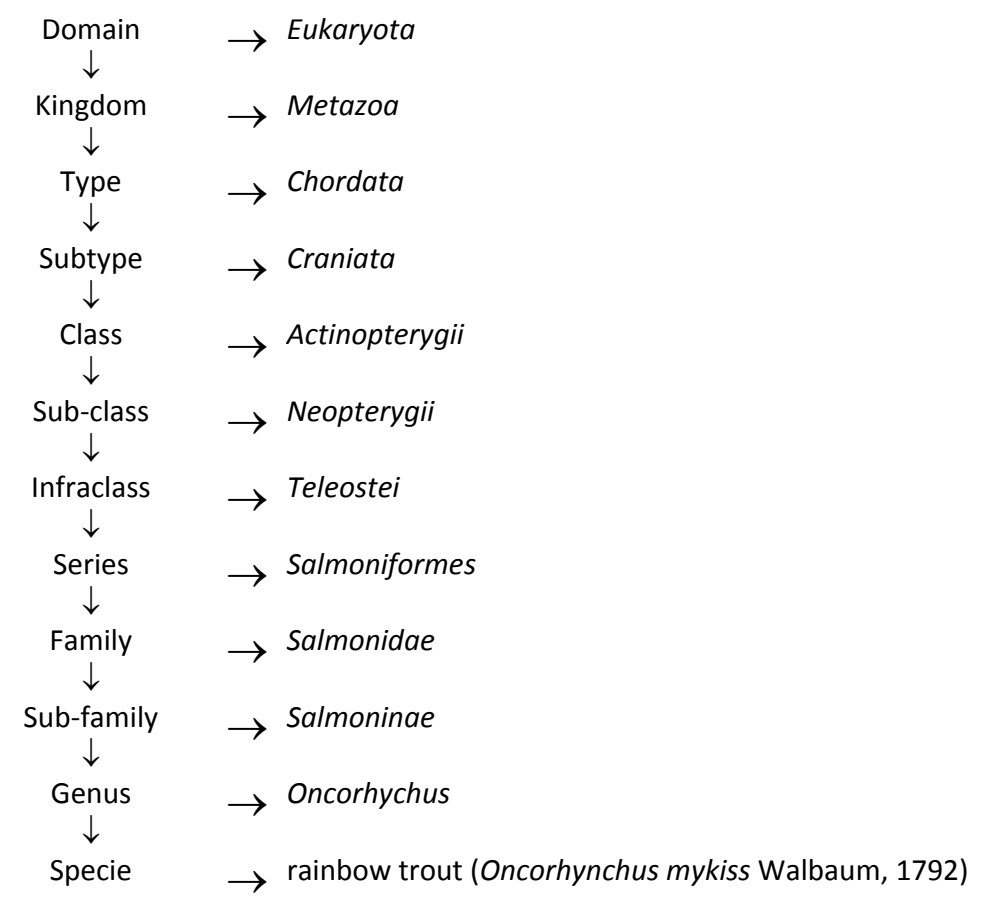

\section{Fig. 1. Hierarchic classification of Oncorhynchus mykiss (Walbaum, 1792)}

Object-oriented programming and hierarchical model of biological objects. Hierarchy of objects is one of cornerstones of object-oriented programming. From the other side, hierarchical model is an extremely important model of objects organization and classification in living Nature [24, 54]. Similarity of these two ideas is a great philosophic problem, but now we are interested in possibility how to use it and other object-oriented programming approaches for the construction of databases with information about biological objects (Fig. 1).; and such databases have to be as more adequate as possible to biological objects hierarchy in the Nature. On Fig. 1 we have 
represented hierarchical scheme of rainbow trout - Oncorhynchus mykiss (Walbaum, 1792) that belongs to the animals from Eukaryota Domain (according to Linne classic hierarchical scheme [54]).

Approach of Object Oriented Analysis (OOA) for analyzing and constructing of models. OOA methods enable to construct the DB with optimal characteristics. This is really important because 1) numerical recordings of DB need great volumes of computer memory and if not to optimize DB structure from the very beginning it cause great memory losses with time; 2) some sectors of DB may be accessible ONLY being linked through the "keys" after OOA and ER-diagram development. In general, OOA is a method, which provides simulation of object model (OM) and formation of requirements for subject space ( $\mathrm{SbS}$ ) by means of a notion "entity-relationship ER", specification of data streams and related processes [55-57].

Analysis of $\mathrm{SbS}$ is carried out using object-oriented methods and corresponding standards. The ultimate objective of the object-oriented analysis of SbS is the definition of the object model (OM) with the help of selected objects, the relations between them and their properties and characteristics. For analytical design of objects, their attributes and relations between them the scheme called ER-diagram was developed. On Fig. 2 we have depicted ER-diagram for the abstract objects "Fish" , "Virus", and "Carrier" of this virus.

It means that in our investigation we united in linked databases the information about fishes (for example, about the rainbow trout Oncorhynchus mykiss), viruses that are the reasons of O.mykiss diseases, and organisms-carriers of these viruses. For example, for O.mykiss it is known that they have such virus diseases: viral hemorrhagic septicemia, trout infectious anemia, infectious necrosis of salivary hematopoietic tissue, herpesvirus disease of salmons, and etc., which are characterized by the high mortality of fishes that causes significant economic losses to world aquaculture.

At the next step we have to describe at one scheme these 3 objects (trout - virus virus carrier) with all their important characteristics and relations between objects. Such scheme one could see on Fig. 2, that is "ER-diagram" for the fish "Rainbow trout". It is necessary to mention that these three objects for our database we picked up on the base of experimental results. In these experiments two groups of fishes were in the pool: salmons and trout [58]. Both species became sick after they had been infected by alfavirus; and Talitrus saltator was the carrier for this alfavirus [58].

ER-diagram description. Objects here are the nouns, the main entities, information about them have to be included into the DB (rectangles): fish, virus, and virus carrier. Attributes there are object characteristics, necessary for object description (ovals): Latin name, native name, location of living, and etc. Relations (rhombus) here mean links that unite the objects if they are logically linked (for example, "trout" is infected by "virus"). Important characteristics of the relations between objects are the "Power of relation" (Fig. 3). If one fish species is infected by one virus strain the "power of relation" is $1: 1$. Similarly, if 1 specie of carrier carries 1 virus strain the "power of relation" is $1: 1$. But if " $\mathrm{M}$ species of fishes were infected by $\mathrm{N}$ strains of viruses" "power of relation" is M:N and so on. More about the art of DB construction one can read in $[1,2,3,24]$. 


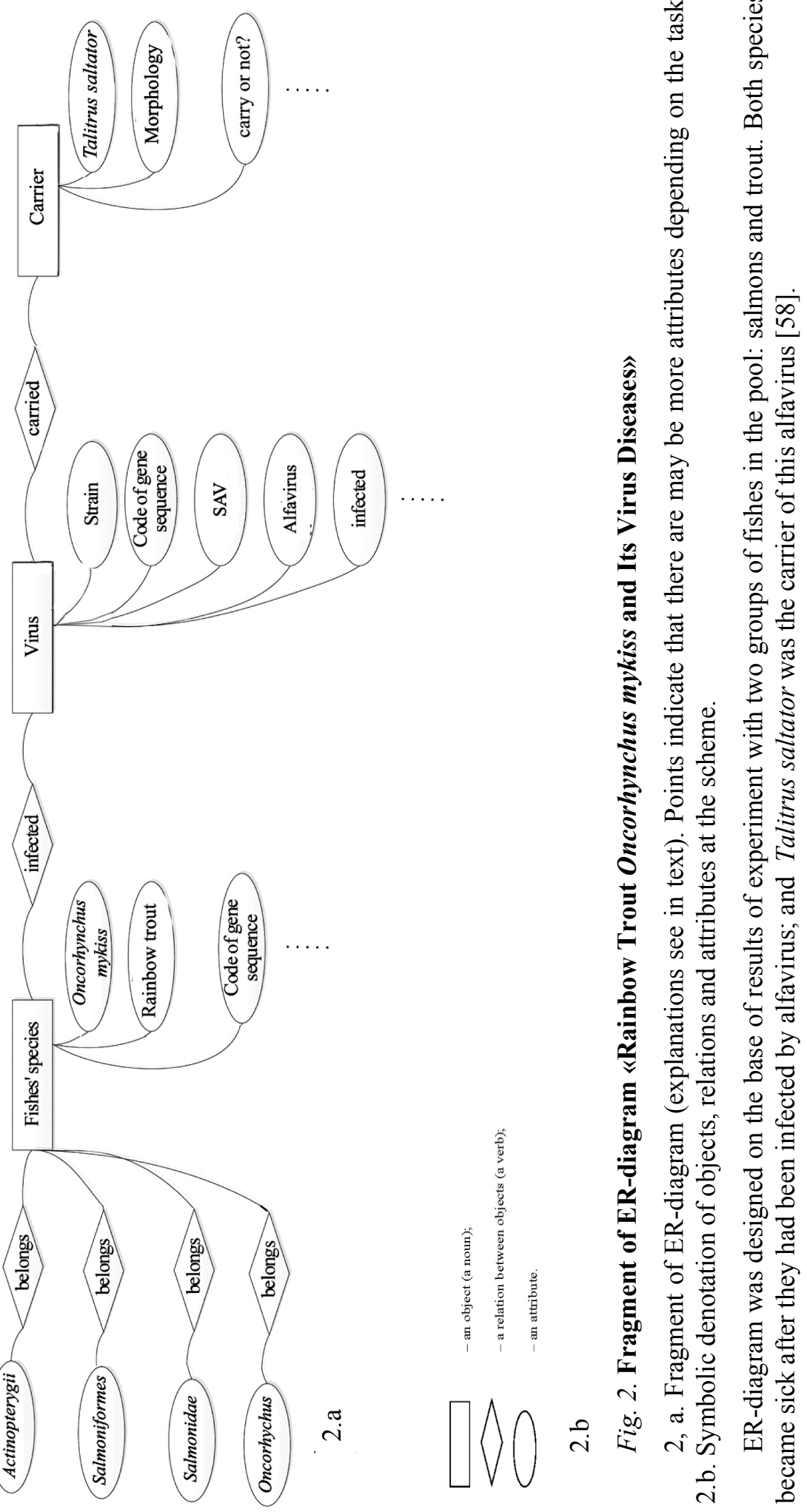




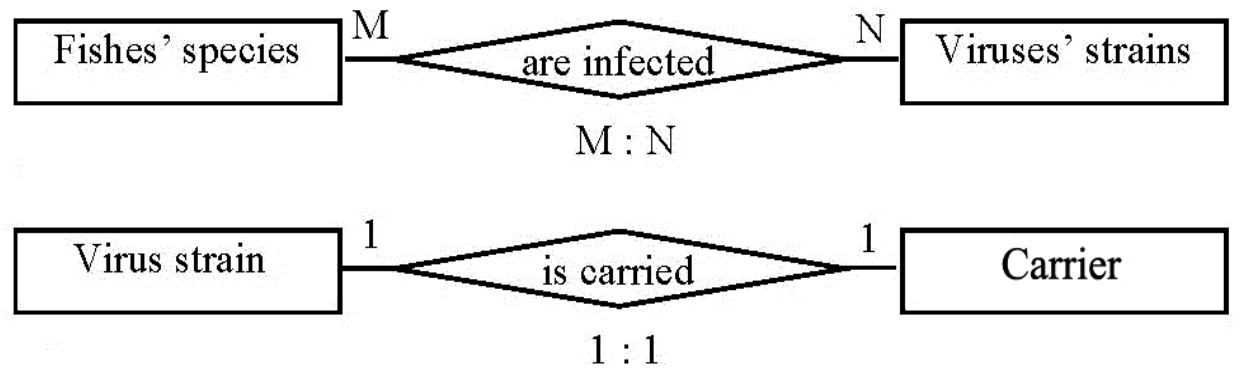

\section{Fig. 3. Power of relations between the 3 objects during the database elaboration.}

Above: "M : N" - "many-to-many". In this example, this means:

"M species of fishes were infected by $\mathrm{N}$ strains of viruses" [1]

Below: "1 : 1" - "one-to-one". In this example, this means:

"1 specie of carrier carries 1 strain of virus"

\section{CONCLUSIONS AND PROSPECTS OF FURTHER DEVELOPMENT}

At the beginning of this article we observed some fish databases known in the world. Than the peculiarities of biological objects that have to be taken into account during DB construction were analyzed. Further the approaches of object-oriented analysis for DB construction in optimal manner were suggested. The first logical steps of algorithm of DB with information about fish (trout) development have been described as well. At this step of DB construction some practical recommendations for the development of databases with information about domestic biological organisms for electronic information systems may be done: maximal accuracy in data mining, standardization of input data about fishes, using of approach of object-oriented system analysis with further ER-diagram designing, and so on.

It is necessary to emphasize the originality of results in the present article. No large-scale implementation of contemporary information-computer technologies in Ukraine was done yet and our findings described in the article will contribute to further intensive development of fishery industry here.

We would like to hope that practical implementation of our work results will have good prospects in Ukraine. Rainbow trout is important specie for fishery economy; it and its viral infections affecting it are of great value for food safety. Information computer technologies applying suggested in the present article, will make this sphere of economy more effective in Ukraine and in the whole world.

\section{BIBLIOGRAPHY}

1. Klyuchko O. M., Buchatsky L. P., Melezhyk, O. V. Biological databases construction using object-oriented system analysis // Biotechnol. Acta. 2019. Vol. 12 (3). P. 5-22.

2. Klyuchko O. M., Klyuchko Z. F. Electronic databases for Arthropods: methods and applications // Biotechnol. Acta. 2018. Vol. 11 (4) P. 28-49. https://doi.org/10.15407/biotech11.04.028.

3. Klyuchko O. M., Klyuchko Z. F. (2018). Electronic information systems for monitoring of populations and migrations of insects. Biotechnol. acta. 2018. Vol. 
11 (5). P. 5-25. https://doi.org/10.15407/biotech11.05.005.

4. Duan Y., Fu Z., Li D. Toward Developing and Using Web-based Tele-Diagnosis in Aquaculture // Expert System ith Applications. 2003. Vol. 25 (2). P. 247-254.

5. Creation of Information retrieval systems on collections of marine animals (fishes and invertebrates) in the Zoological Institute of RAS / Smirnov I. S. et al. // Sixth National Russian Research Conference RCDL'2004, Pushchino, September 29 October 1, 2004 : proceed. Moscow, 2004. P. 30-33.

6. FVD: The fish-associated virus database / Chen Y. et al. // Infect Genet. 2018. Vol. 58. P. 23-26. doi: 10.1016/j.meegid.2017.11.004.

7. Crane M., Hyatt A. Viruses of fish: an overview of significant pathogens // Viruses. 2011. Vol. 3 (11). P. 2025-2046. doi: 10.3390/v3112025.

8. Zhang Q., Gui J. F. Virus genomes and virus-host interactions in aquaculture animals // Sci. China Life Sci. 2015. Vol. 58 (2). P. 156-169. doi: 10.1007/s11427-015-4802-y.

9. Using eDNA to biomonitor the fish community in a tropical oligotrophic lake / Valdez-Moreno M. et al. // PloS One. 2019. Vol. 14 (4). e0215505. doi: 10.1371/journal.pone.0215505.

10. Differentiation and Authentication of Fishes at Species Level Through Analysis of Fish Skin by MALDI TOF MS / Bi H. et al. // Rapid Commun. Mass. Spectrom. 2019. doi: $10.1002 / \mathrm{rcm} .8474$.

11. User Reference for Fisheries Improvement ProjectsDatabase (FIP-DB) and Query Viewer. URL: https://ru.scribd.com/document/385739269/Readme-File-for-FIPDB\#download (accessed: 01.08.2019).

12. Froese R., Pauli D. FishBase 2000: Concepts, designs and data sources. Los Banos, Philippines : ICLARM, 2000.

13. Moreau J., Costa-Pierce B. Introduction and present status of exotic carp in Africa // Aquacult. Res. 1997. Vol. 28. P. 717-732.

14. The State of World Fisheries and Aquaculture 2016. Contributing to food security and nutrition for all. Rome : FAO, 2016. 200 p. URL: http://www.fao.org/3/ai5555e.pdf (accessed: 01.08.2019).

15. Effects of Global Climate Change on Marine and Estuarine Fishes and Fisheries / Roessig J. M. et al. [S. 1.] : Springer, 2004.

16. A Global Information System on Fishes. URL: https://www.fishbase.se/home.htm (accessed: 01.08.2019).

17. A database of fish biotransformation rates for organic chemicals / Arnot J. A. et al. // Environmental Toxicology and Chemistry. 2008. Vol. 27 (11). P. 2263-2270. URL: https://setac.onlinelibrary.wiley.com/doi/full/10.1897/08-058.1. doi: 10.1897/08-058.1 (accessed: 01.08.2019).

18. A global database on freshwater fish species occurrence in drainage basins / Tedesco P. A. et al. // Sci. Data. 2017. Vol. 4. 170141. doi: 10.1038/sdata.2017.141.

19. Van der Laan R., Eschmeyer W. N., Fricke R. Family-group names of Recent fishes // Zootaxa Monograph. 2014. Vol. 3882 (1). P. 1-230. doi:10.11646/zootaxa.3882.1.1.

20. Fricke R., Eschmeyer W. N., van der Laan R. Eschmeyer's catalog of fishes: genera, $\quad$ species. $2019 . \quad$ URL: http://researcharchive.calacademy.org/research/ichthyology/ catalog (accessed: 01.08.2019).

21. Zeldis D., Prescott S. Fish disease diagnosis program-Problems and some solutions // Aquacultural Engineering. 2000. Vol. 23 (1-3). P. 3-11. 
22. Daoliang Li, Zetian Fu, Yanqing Duan. (2002). Fish-Expert: a web-based expert system for fish disease diagnosis // Expert Systems with Applications. 2002. Vol. 23. P. 311-320.

23. Frimpong E. A., Paul L. Welcome to the FishTraits Database. URL: http://www.fishtraits.info (accessed: 01.08.2019).

24. SalmonDB: a bioinformatics resource for Salmo salar and Oncorhynchus mykiss. Database / Di Génova A. D. et al. Oxford, 2011: bar050. doi: 10.1093/database/bar050. URL: https:/www.ncbi.nlm.nih.gov/pmc/articles/ PMC3225076 (accessed: 01.08.2019).

25. Ключко О. М. Інформаційно-комп'ютерні технології в біології та медицині. Київ : НАУ-друк, 2008. 282 с.

26. Майстренко М. І., Рудь Ю. П., Бучацький Л. П. Накопичення вірусу інфекційного панкреатичного некрозу на культурах клітин риб // Біологія тварин. 2014. Т. 16, № 4. С. 93-99.

27. Matvienko N. M., Buchatsky L. P. The use of immunomodulating preparations in fish farming // Modern problems of theoretical and practical ichthyology. 2014. P. 33-35 (In Ukrainian).

28. New hosts of the third-type of carp herpes virus (CyHV-3) / Gavrilova I. P. et al. // Scientific notes of the Ternopil Ped. University. Series Biology. 2014. Vol. 58 (1). P. 16-20 (In Ukrainian).

29. Maistrenko M. I., Buchatsky L. P. (2014). Biology of Herpesvirus Fish // Problems of ecological and medical genetics and clinical immunology. 2014. Vol. 3 (123). P. 19-35 (In Ukrainian).

30. Experimental infection of long-winded cancer (Pontastacus leptodactylus) with virus of infectious pancreatic necrosis / Rud Yu. P. et al. // Bulletin of Biology and Medicine. 2014. Is. 4, 1 (113). P. 70-74 (In Ukrainian).

31. Matvienko N., Rud Yu., Buchatsky L. (2014). Replication of infectious pancreatic necrosis virus in different cell lines and organism of rainbow trout (Oncorhynchus mykiss) fingerlings // Arch. Pol. Fish. 2014. Vol. 222. P. 127-133.

32. Matvienko N. M., Buchatsky L. P. Study of reproduction of hemorrhagic septicemia trout virus // Bulletin of Problems of Biology and Medicine. Is. 2 (3). P. 118-121 (In Russian).

33. Matvienko N. M., Buchatsky L. P., Deriabin O. M. Application of a reverse transcriptase polymerase chain reaction for the detection and identification of the virus of infectious pancreatic necrosis of rainbow trout (Oncorhynchus mykiss) // Microbiology and biotechnology. 2013. Vol. 4 (24). P. 46-54 (In Ukrainian).

34. Characteristics of spring viraemia of carp virus strains isolated in different regions of Ukraine / Matvienko N. et al. // Zoology and Ecology. 2013. Vol. 23 (3). P. $198-202$.

35. Matvienko N., Rud Y., Buchatsky L. (2013). Replication of infectious pancreatic necrosis virus in different cell lines and organism of rainbow trout (Oncorhynchus mykiss) fingerlings // Archives of Polish Fisheries. 2013. Iss. 4. P. 127-133.

36. Rud Yu. P., Maistrenko M. I., Buchatsky L. P. (2013). Amplification and analysis of the nucleotide sequence of VP2 TA NS IPNV genes isolated in Western Ukraine // Problems of ecological and medical genetics and clinical immunology. 2013. Vol. 4 (118). P. 34-40 (In Ukrainian).

37. Штам герпесвірусу коі (KHV) IMB V-4 для отримання вакцини проти вірусу герпесу коі : пат. 79945 Україна. № u201212254 ; заявл. 26.10.2012 ; опубл. 13.05.2013, Бюл. № 9. 
38. Rud Yu., Maistrenko M., Buchatsky L. Isolation of IPNV from wild-life rainbow trout (Oncorhynchus mykiss) in Western Ukraine // Biology. 2013. Vol. 3 (65). P. $63-65$.

39. Identification of virus SyNV-3 by the methods of electron microscopy and polymerase chain reaction / Maistrenko M. I. et al. // Reports of the National Academy of Sciences of Ukraine. 2013. Vol. 4. P. 139-143 (In Ukrainian).

40. Results of surveillance studies of infectious fish diseases in freshwater aquaculture of Ukraine / Matvienko N. M. et al. // Agricultural science and practice. 2015. Vol. 2 (2). P. 32-38.

41. Rud Y. P., Buchatsky L. P. Detection of infectious pancreatic necrosis virus in the western Ukraine // Virologica sinica. 2015. Vol. 30 (2). P. 1-4.

42. Movchan $\mathrm{Yu}$. V. Fishes of Ukraine (taxonomy, nomenclature, remarks) // Collection of works of Zoological Museum. 2009. Vol. 40. P. 47-87.

43. Спосіб проведення моніторингу впливу хімічних речовин на біоорганізми у кількох інтервалах часу пат. 134575 Україна. № u201812443 ; заявл. 14.12.2018; опубл. 27.05.2019, Бюл. № 10.

44. Klyuchko O. M. On the mathematical methods in biology and medicine // Biotechnol. Acta. 2017. Vol. $10 \quad$ (3). $\quad$ P. $31-40$. https://doi.org/10.15407/biotech10.03.031.

45. Klyuchko O. M. Application of artificial neural networks method in biotechnology // Biotechnol. Acta. 2017. Vol. 10 (4). P. 5-13. https://doi.org/10.15407/biotech10.04.005.

46. Klyuchko O. M. Cluster analysis in biotechnology // Biotechnol. Acta. 2017. Vol. 10 (5). P. 5-18. https://doi.org/10.15407/biotech10.05.005.

47. Klyuchko O. M., Onopchuk Yu. M. Some trends in mathematical modeling for biotechnology // Biotechnol. Acta. 2018. Vol. 11 (1). P. 39-57. https://doi.org/10.15407/biotech11.01.039.

48. Klyuchko O. M. Electronic information systems in biotechnology // Biotechnol. Acta. 2018. Vol. 11 (2). P. 5-22. https://doi.org/10.15407/biotech11.02.005.

49. Klyuchko O. M. Information computer technologies for biotechnology: electronic medical information systems // Biotechnol. Acta. 2018. Vol. 11 (3). P. 5-26. https://doi.org/10.15407/biotech11.03.005.

50. Klyuchko O. M. Expert systems for biology and medicine // Biotechnol. Acta. 2018. Vol. 11 (6). P. 5-28. https://doi.org/10.15407/biotech11.06.005.

51. Klyuchko O. M. Biotechnical information systems for monitoring of chemicals in environment: biophysical approach // Biotechnol. Acta. 2019. Vol. 12 (1). P. 5-28.

52. Klyuchko O. M., Aralova N. I., Aralova A. A. Electronic automated work places for biological investigations // Biotechnol. Acta. 2019. Vol. 12 (2). P. 5-22.

53. Sachnyuk G. V., Melezhyk O. V. Current state of water resources protection against pollution // Youth: education, science, spirituality : XV Ukr. Sci. conf. Kyiv, April 17-19 : theses of reports. Kyiv, 2007. P. 409-410.

54. Schnase J. L., Cushing J., Frame M. Information technology challenges of biodiversity and ecosystems informatics // Inform. syst. 2003. Vol. 28 (4). P. 339345.

55. Linne C. Fauna Suecica. Stocholmiac, 1761.

56. Microsoft Academy: Methods and means of software engineering. URL: https://www.intuit.ru/studies/courses/2190/237/lecture/6124 (accessed: 01.08.2019). 
57. Хомоненко А. Д. Базы данных : учебник. 5-е изд., доп. Санкт-Петербург : Корона Принт ; Москва : Бином-Пресс, 2006. 736 с.

58. Harrington Jan L. Object-oriented database design clearly explained. USA: Academic Press, 2005.

59. Бучацький Л. П. Альфавірусні хвороби лососевих риб // Рибогосподарська наука України. 2012. № 1. С. 105-110.

\section{REFERENCES}

1. Klyuchko, O. M., Buchatsky, L. P., \& Melezhyk, O. V. (2019). Biological databases construction using object-oriented system analysis. Biotechnol. acta, 12 (3), 5-22.

2. Klyuchko, O. M., \& Klyuchko, Z. F. (2018). Electronic databases for Arthropods: methods and applications. Biotechnol. acta, 11 (4), 28-49. https://doi.org/10.15407/biotech11.04.028.

3. Klyuchko, O. M., \& Klyuchko, Z. F. (2018). Electronic information systems for monitoring of populations and migrations of insects. Biotechnol. acta, 11 (5), 5-25. https://doi.org/10.15407/biotech11.05.005.

4. Duan, Y., Fu, Z., \& Li, D. (2003). Toward Developing and Using Web-based TeleDiagnosis in Aquaculture. Expert System with Applications, 25 (2), 247-254.

5. Smirnov, I. S., Voronina, E. P., Lobanov, A. L., Golikov, A. A., \& Neyelov, A. V. (2004). Creation of Information retrieval systems on collections of marine animals (fishes and invertebrates) in the Zoological Institute of RAS. Proceedings of the Sixth National Russian Research Conference RCDL'2004, Pushchino, September 29 - October 1, 2004. Moscow, 30-33.

6. Chen, Y., Shi, M., Cheng, Y., Zhang, W., Tang, Q., \& Xia, Q. (2018). FVD: The fish-associated virus database. Infect Genet., 58, 23-26. doi: 10.1016/j.meegid.2017.11.004.

7. Crane, M., \& Hyatt, A. (2011). Viruses of fish: an overview of significant pathogens. Viruses, 3 (11), 2025-2046. doi: 10.3390/v3112025.

8. Zhang, Q., \& Gui, J. F. (2015). Virus genomes and virus-host interactions in aquaculture animals. Sci. China Life Sci., 58 (2), 156-169. doi: 10.1007/s11427015-4802-y.

9. Valdez-Moreno, M., Ivanova, V., Elías-Gutiérrez, M., Pedersen, L., Bessonov, K., \& Hebert, N. (2019). Using eDNA to biomonitor the fish community in a tropical oligotrophic lake. PloS One, 14 (4), e0215505. doi: 10.1371/journal.pone.0215505.

10. Bi, H., Zhong, C., Shao, M., Wang, C., Yi, J., Qiao, L., \& Zhang, J. (2019). Differentiation and Authentication of Fishes at Species Level Through Analysis of Fish Skin by MALDI TOF MS. Rapid Commun. Mass. Spectrom. doi: $10.1002 / \mathrm{rcm} .8474$.

11. User Reference for Fisheries Improvement ProjectsDatabase (FIP-DB) and Query Viewer. ru.scribd.com. Retrieved from https://ru.scribd.com/document/385739269/Readme-File-for-FIP-DB\#download.

12. Froese, R., \& Pauli, D. (2000). FishBase 2000: Concepts, designs and data sources. Los Banos, Philippines: ICLARM.

13. Moreau, J., \& Costa-Pierce, B. (1997). Introduction and present status of exotic carp in Africa. Aquacult. Res., 28, 717-732.

14. FAO. (2016). The State of World Fisheries and Aquaculture 2016. Contributing to food security and nutrition for all. Rome. 200 p. fao.org. Retrieved from 
http://www.fao.org/3/a-i5555e.pdf.

15. Roessig, J. M., Woodley, Ch. M., Cech, J. J., \& Hansen L. J. (2004). Effects of Global Climate Change on Marine and Estuarine Fishes and Fisheries. Springer.

16. A Global Information System on Fishes. fishbase.se. Retrieved from https://www.fishbase.se/home.htm.

17. Arnot, J. A., Mackay, D., Parkerton, T. F., \& Bonnell, M. (2008). A database of fish biotransformation rates for organic chemicals. Environmental Toxicology and Chemistry, $27 \quad$ (11), 2263-2270. Retrieved from https://setac.onlinelibrary.wiley.com/doi/full/10.1897/08-058.1. doi: 10.1897/08058.1 .

18. Tedesco, P. A., Beauchard, O., Bigorne, R., Blanchet, S., Buisson, L., Conti, L., Cornu, J.-F., Dias, M. S., Grenouillet, G., Hugueny, B., Jézéquel, C., Leprieur, F., Brosse, S., \& Oberdorff, T. (2017). A global database on freshwater fish species occurrence in drainage basins. Sci. Data, 4, 170141. doi: 10.1038/sdata.2017.141.

19. Van der Laan, R., Eschmeyer, W. N., \& Fricke, R. (2014). Family-group names of Recent fishes. Zootaxa Monograph., $3882 \quad$ (1), $1-230$. doi:10.11646/zootaxa.3882.1.1.

20. Fricke, R., Eschmeyer, W. N., \& van der Laan, R. Eschmeyer's catalog of fishes: genera, species, 2019. researcharchive.calacademy.org. Retrieved from: http://researcharchive.calacademy.org/research/ichthyology/catalog.

21. Zeldis, D. \& Prescott, S. (2000). Fish disease diagnosis program-Problems and some solutions. Aquacultural Engineering, 23 (1-3), 3-11.

22. Daoliang, Li, Zetian, Fu, \& Yanqing, Duan. (2002). Fish-Expert: a web-based expert system for fish disease diagnosis. Expert Systems with Applications, 23, 311320.

23. Frimpong, E. A., \& Paul, L. Welcome to the FishTraits Database. fishtraits.info. Retrieved from http://www.fishtraits.info.

24. Di Génova, A. D., Aravena, A., Zapata, L., González, M., Maass, A., \& Iturra, L. (2011). SalmonDB: a bioinformatics resource for Salmo salar and Oncorhynchus mykiss. Database (Oxford). 2011: bar050. doi: 10.1093/database/bar050. ncbi.nlm.nih.gov. Retrieved from https:/www.ncbi.nlm.nih.gov/pmc/articles/ PMC3225076.

25. Klyuchko, O. M. (2008). Information and computer technologies in biology and medicine. Kyiv: Nat. Acad. Scienc. Ukraine-druk. (In Ukrainian).

26. Maistrenko, M. I., Rud, Yu. P., \& Buchatsky, L. P. (2014). Accumulation of IPNV on the culture of fish cells. Animal Biology, 16 (4), 93-99 (In Ukrainian).

27. Matvienko, N. M., \& Buchatsky, L. P. (2014). The use of immunomodulating preparations in fish farming. Modern problems of theoretical and practical ichthyology, 33-35 (In Ukrainian).

28. Gavrilova, I. P., Maistrenko, M. I., Rumar, V. I., Buchatsky, L. P., \& Rud, Yu. P. (2014). New hosts of the third-type of carp herpes virus (CyHV-3). Scientific notes of the Ternopil Ped. University. Series Biology, 58 (1), 16-20 (In Ukrainian).

29. Maistrenko, M. I., \& Buchatsky, L. P. (2014). Biology of Herpesvirus Fish. Problems of ecological and medical genetics and clinical immunology, 3 (123), 1935 (In Ukrainian).

30. Rud, Yu. P., Maistrenko, M. I., Bezusy, O. L. \& Buchatsky, L. P. (2014). Experimental infection of long-winded cancer (Pontastacus leptodactylus) with virus of infectious pancreatic necrosis. Bulletin of Biology and Medicine, 4, 1 (113), 70-74 (In Ukrainian). 
31. Matvienko, N., Rud, Yu., \& Buchatsky, L. (2014). Replication of Infectious Pancreatic Necrosis Virus in different cell lines and organism of rainbow trout (Oncorhynchus mykiss) fingerlings. Arch. Pol. Fish., 222, 127-133.

32. Matvienko, N. M., \& Buchatsky, L. P. Study of reproduction of hemorrhagic septicemia trout virus. Bulletin of Problems of Biology and Medicine, 2 (3), 118121 (In Russian).

33. Matvienko, N. M., Buchatsky, L. P., \& Deriabin, O. M. (2013). Application of a reverse transcriptase polymerase chain reaction for the detection and identification of the virus of infectious pancreatic necrosis of rainbow trout (Oncorhynchus mykiss). Microbiology and biotechnology, 4 (24), 46-54 (In Ukrainian).

34. Matvienko, N., Kharkavlyuk, N., Buchatsky, L., \& Didenko A. (2013). Characteristics of spring viraemia of carp virus strains isolated in different regions of Ukraine. Zoology and Ecology, 23 (3), 198-202.

35. Matvienko, N., Rud, Y., \& Buchatsky, L. (2013). Replication of infectious pancreatic necrosis virus in different cell lines and organism of rainbow trout (Oncorhynchus mykiss) fingerlings. Archives of Polish Fisheries, 4, 127-133.

36. Rud, Yu. P., Maistrenko, M. I., \& Buchatsky, L. P. (2013). Amplification and analysis of the nucleotide sequence of VP2 TA NS IPNV genes isolated in Western Ukraine. Problems of ecological and medical genetics and clinical immunology, 4 (118), 34-40 (In Ukrainian).

37. Maistrenko, M. I., Buchatsky, L. P., \& Matvienko, N. M. (2013). Strain of herpesvirus IMB B-4 for the obtaining a vaccine against herpes virus koi. Patent of Ukraine. (In Ukrainian).

38. Rud, Yu., Maistrenko, M., \& Buchatsky, L. (2013). Isolation of IPNV from wildlife rainbow trout (Oncorhynchus mykiss) in Western Ukraine. Biology, 3 (65), 6365.

39. Maistrenko, M. I., Rud, Yu. P., Matvienko, N. M., Cholodna, L. S., \& Buchatsky, L. P. (2013). Identification of virus SyNV-3 by the methods of electron microscopy and polymerase chain reaction. Reports of the National Academy of Sciences of Ukraine, 4, 139-143 (In Ukrainian).

40. Matvienko, N. M., Vashchenko, A. V., Tsiganok, I. O., \& Buchatsky, L. P. (2015). Results of surveillance studies of infectious fish diseases in freshwater aquaculture of Ukraine. Agricultural science and practice, 2 (2), 32-38.

41. Rud, Y. P., \& Buchatsky, L. P. (2015). Detection of infectious pancreatic necrosis virus in the Western Ukraine. Virologica sinica, 30 (2), 1-4.

42. Movchan, Yu. V. (2009). Fishes of Ukraine (taxonomy, nomenclature, remarks). Collection of works of Zoological Museum, 40, 47-87.

43. Klyuchko, O. M. (2018). Method for monitoring of chemicals influence on bioorganisms in few time intervals. Patent of Ukraine №134575 (In Ukrainian).

44. Klyuchko, O. M. (2017). On the mathematical methods in biology and medicine. Biotechnol. acta, 10 (3), 31-40. https://doi.org/10.15407/biotech10.03.031.

45. Klyuchko, O. M. (2017). Application of artificial neural networks method in $\begin{array}{lllll}\text { biotechnology. } \quad \text { Biotechnol. } & \text { acta, } & 10 & \text { (4), }\end{array}$ https://doi.org/10.15407/biotech10.04.005.

46. Klyuchko, O. M. (2017). Cluster analysis in biotechnology. Biotechnol. acta, 10 (5), 5-18. https://doi.org/10.15407/biotech10.05.005.

47. Klyuchko, O. M., \& Onopchuk Yu. M. (2018). Some trends in mathematical modeling for biotechnology. Biotechnol. acta, 11 (1), 39-57. https://doi.org/10.15407/biotech11.01.039. 
48. Klyuchko, O. M. (2018). Electronic information systems in biotechnology. Biotechnol. acta, 11 (2), 5-22. https://doi.org/10.15407/biotech11.02.005.

49. Klyuchko, O. M. (2018). Information computer technologies for biotechnology: electronic medical information systems. Biotechnol. acta, 11 (3), 5-26. https://doi.org/10.15407/biotech11.03.005.

50. Klyuchko, O. M. (2018). Expert systems for biology and medicine. Biotechnol. acta, 11 (6), 5-28. https://doi.org/10.15407/biotech11.06.005.

51. Klyuchko, O.M. (2019). Biotechnical information systems for monitoring of chemicals in environment: biophysical approach. Biotechnol. acta, 12 (1), 5-28.

52. Klyuchko, O. M., Aralova, N. I., \& Aralova, A. A. (2019). Electronic automated work places for biological investigations. Biotechnol. acta, 12 (2), 5-22.

53. Sachnyuk, G. V., \& Melezhyk, O. V. (2007). Current state of water resources protection against pollution. Youth: education, science, spirituality: theses of reports XV Ukr. Sci. conf. Kyiv, April 17-19, 409-410.

54. Schnase, J. L., Cushing, J., \& Frame, M. (2003). Information technology challenges of biodiversity and ecosystems informatics. Inform. syst., 28 (4), 339-345.

55. Linne, C. (1761). Fauna Suecica. Stocholmiac.

56. Microsoft Academy: Methods and means of software engineering. intuit.ru. Retrieved from https://www.intuit.ru/studies/courses/2190/237/lecture/6124.

57. Chomonenko, A. D., Tzygankov, V. M., \& Maltzev, M. G. (2006). Databases. (5th edn.). Moscow: Binom Press. (In Russian).

58. Harrington, Jan L. (2005). Object-oriented database design clearly explained. USA: Academic Press.

59. Buchatsky, L. P. (2012). Alfaviral diseases of salmon fishes. Fisheries science of Ukraine, 1, 105-110 (In Ukrainian). 